\title{
Determination of Data Mining Application Design Patterns Booking Raw Food In Restaurant Fountain With Apriori Algorithm
}

\author{
Risnamawati Ndruru ${ }^{1}$,Paska Marto Hasugian ${ }^{2}$ \\ ${ }^{1.2}$ Informatics Engineering Program, STMIK Pelita Nusantara Medan, Jl. Iskandar Muda 1 \\ Medan, North Sumatra 20154, Indonesia \\ E-mail: Risnamawati_ndruru@gmail.com
}

\begin{abstract}
Booking is an activity carried out by certain parties to ensure availability, in carrying out certain activities the company has a supply of material in quantities that exceed the needs. As a result, in the warehouse there is a buildup of raw materials or it can happen otherwise. Inventories of materials that are too small can hinder the company's operations in the form of unavailability of materials when needed. The role of inventory will determine the operation of the company because the inventory will run well if supported by good management. Therefore, the concept of inventory management that affects ordering is very important to be applied by companies so that the goals of effectiveness and efficiency are achieved. So we need a Data Mining that can quickly to determine the Determination of Food Raw Material Ordering Patterns in Restaurant Fountain Using Apriori. Data Mining is the extraction of new information taken from large chunks of data that helps in making decisions. One of the applications of data mining for Determining the Pattern of Ordering Food Raw Materials in Restaurant Fountain Using Apriori. Apriori method is a method for determining frequent itemsets for boolean association rules. The research aims to build the application of Determining the Pattern of Ordering Food Raw Materials in Restaurant Fountain with a web-based application and as a tool for designing applications using the Mysql Database. This data mining is able to determine the ordering of food items in the Restaurant Fountain with the required amount.
\end{abstract}

Keywords: Determination of Food Raw Material Ordering Pattern, Data Mining, Apriori method.

\section{Introduction}

The current technology development needs for more accurate information is needed in everyday life, so that the information will be an important element in the development of society, but a high information needs sometimes is not matched with adequate information presentation. The ability of information technologies to collect and store various types of data outpacing the ability to analyze, summarize and extract knowledge from data. The traditional method for analyzing the data, it can not handle large amounts of data, one of the roles of technology role in the booking rate of Materials.

Booking is an activity undertaken by certain parties to ensure the availability, in carrying out certain activities Companies have supplies in excess of needs. As a result, in a warehouse in the accumulation of raw materials or can be otherwise. Supplies materials that are too small may hinder the company's operations in the form of unavailability of materials when needed. The role of the inventory will determine the operation of the company because the supply will run well if it is supported by good management. Therefore, the concept of inventory management that affect bookings are essential implemented by the company to the effectiveness and the efficiency of goal achieved.

Based on research conducted in Retaurant Fountaian a purchase transaction raw material inventory. Purchase transaction data inventories of raw materials is growing every day and at the Restaurant of the sales transaction data is only stored as archives or books and it is unknown what the benefits of the data available for other activities. Raw material inventory ordering system in Restaurant Fountaian not run well because sales data contained in the books is only allowed to accumulate and growing unbeknown to any further such data. Hence Restaurant Fountaian require the system to process the data to produce a pattern Booking raw materials are most often purchased to be a reference to increase the stock of raw material inventory is depleted raw material inventories are rarely to be purchased. One data processing techniques that can be used to issue the stretcher is a priori algorithm.

\section{Theory}

\subsection{Data Mining}

data mining as a process to obtain useful information to warehouse large data base. Data mining can also be interpreted as extracting new information retrieved from large data chunks that help in decision making. The term data mining is sometimes also called knoweledge discovery. One technique that was made in data mining 
is how to discover existing data to build a model. Then, using the model in order to identify the pattern of other data that are not in the data base stored. Prediction needs can also take advantage of this technique. In data mining, data grouping is also done. The aim is that suppose to know the universal pattern of existing data

2.2 apriori

Apriori is a basic algorithm proposed by Agrawal and Srikant in 1994 for the determination of frequent itemsets for association rules boolean, Priori algorithms including the type of association rules in data mining. A rule that states the association between some attributes often called affinity analysis or market basket analysis. Analysis association or association rule mining is data mining techniques to discover the rules of a combination of items. One association analysis stage that attracted the attention of many researchers to produce efficient algorithms is the analysis of patterns of high frequency (frequent pattern mining). Important or not an association can be seen with the two benchmarks, namely: support and confidence. Support (support value) is the percentage of the combination of those items in the database, while confidence (certainty value) is the strong relationship between items in the rules of the association.

Support an item value is obtained by using the formula:

$$
\text { support } A=\frac{\text { jumla冈 transaksi mengandung } A}{\text { total transaksi }}
$$

Meanwhile, the value of support of 2 items obtained by using the formula:

$$
\begin{gathered}
\text { suppotr } A, B=P A \otimes B \\
\text { support } A, B=\frac{\text { transaksi mengandung } A \text { dan } B}{\text { transaksi }}
\end{gathered}
$$

\section{Analysis}

a. Table list of raw materials

Here is a table type of feedstock materials in restourant fountain.

Table 1

List of feedstock materials in the restaurant fountain

\begin{tabular}{lll}
\hline No. & Material code & \multicolumn{1}{c}{ name of Material } \\
\hline 1. & BB000101 & Broccoli \\
2. & BB000201 & Cabbage \\
3. & BB000301 & Swamp cabbage \\
4. & BB000401 & Bean \\
5. & BB000501 & broccoli flowers \\
6. & BB000601 & Sawi \\
7. & BB000701 & Carrot \\
8. & BB000801 & Tomato \\
9. & BB000901 & onions prey \\
10. & BB001001 & Celery \\
11. & BB001101 & Chili \\
12. & BB001201 & onions prey \\
13. & BB001301 & Bombay \\
14. & BB001401 & paprika \\
15. & BB001501 & Lettuce \\
16. & BB001601 & Cucumber \\
17. & BB001701 & Tempe \\
18. & BB001801 & Know \\
19. & BB001901 & Corn \\
20. & BB002001 & Beef \\
21. & BB002101 & Shrimp \\
22. & BB002201 & Dori fish meat \\
23. & BB002301 & Mongolian meat \\
24. & BB002401 & The calamari \\
25. & BB002501 & Chicken meat \\
26. & BB002601 & Egg \\
27. & BB002701 & Rice \\
28. & BB002801 & Pasta \\
\hline & & \\
\hline
\end{tabular}


Journal of Computer Networks, Architecture and High Performance Computing e-ISSN 2655-9102, Volume 2, No. 2, July 2020, pp 275-282

\begin{tabular}{|c|c|c|}
\hline No. & Material code & name of Material \\
\hline 29. & BB002901 & Flour \\
\hline 30. & BB003001 & cooking oil \\
\hline 31. & BB003101 & Soy sauce \\
\hline 32. & BB003201 & Sauce \\
\hline 33. & BB003301 & Broth \\
\hline 34. & BB003401 & Milk \\
\hline 35. & BB003501 & Sausage \\
\hline 36. & BB003601 & Cheese \\
\hline 37. & BB003701 & Bread \\
\hline 38. & BB003801 & Salt \\
\hline 39. & BB003901 & Pepper \\
\hline 40. & BB004001 & Potato \\
\hline 41. & BB004101 & Cassava \\
\hline 42. & BB004201 & mushroom \\
\hline 43. & BB004301 & Banana \\
\hline 44. & BB004401 & Pineapple \\
\hline 45. & BB004501 & tuber \\
\hline 46. & BB004601 & Kincong \\
\hline 47. & BB004701 & Mie \\
\hline 48. & BB004801 & Coconut \\
\hline 49. & BB004901 & Turmeric \\
\hline 50. & BB005001 & Peas \\
\hline
\end{tabular}

b. table Transactions

Transactions in the table are the number of transactions and what is purchased.

Table 2

table of transactions

\begin{tabular}{ll}
\hline $\begin{array}{l}\text { Transactio } \\
\mathrm{n}\end{array}$ & Materials purchased \\
\hline 1 & Vegetables Broccoli, Cabbage vegetables, \\
2 & mustard, Squid \\
3 & Prey Onion, Cucumber, Tomato \\
4 & Chicken meat, calamari, egg, onion Prey \\
5 & Beans, Eggs, Beef \\
6 & Corn, Calamari, Beef \\
7 & Potatoes, Eggs \\
8 & Onions Prey, Chicken, Beef \\
9 & Squid, bean, eggs, tomatoes \\
10 & Chicken, Cucumber, Squid \\
11 & Vegetable broccoli, mustard greens, corn, \\
12 & beans \\
13 & Onions Prey, Chicken, Corn, Potatoes \\
14 & Potatoes, Beef \\
15 & Tomatoes, calamari, Eggs \\
16 & Vegetables Broccoli, Tomatoes, Beans, Onions \\
17 & Prey \\
18 & Beef, Potatoes, Onions Prey \\
19 & Beans, Eggs \\
20 & Prey Onion, Cucumber, Potatoes \\
\hline
\end{tabular}

c. Pattern Analysis of High Frequency

Looking Quantity (Total) given minimum values $\Phi=2$ of 20 transactions.

Step 1: Representation Data Transactional Database Transactions in the following data: 